\title{
From pluralism to perspectivism
}

\section{Tuori, Kaarlo Heikki}

Edward Edgar

2018-05-25

Tuori , K H 2018 , From pluralism to perspectivism . in G Davies \& M Avbelj (eds), Research Handbook on Legal Pluralism and EU Law . Research Handbooks in European Law , Edward Edgar, Cheltenham , pp. 39-56 . https://doi.org/10.4337/9781786433091

cc_by_nc

publishedVersion

Downloaded from Helda, University of Helsinki institutional repository.

This is an electronic reprint of the original article.

This reprint may differ from the original in pagination and typographic detail.

Please cite the original version. 


\section{From pluralism to perspectivism Kaarlo Tuori}

\section{TWO READINGS OF THE PLURALIST SITUATION}

Ever since Neil MacCormick's pathbreaking articles in the $1990 \mathrm{~s},{ }^{1}$ the overt or covert caselaw ping-pong between the German Constitutional Court (GCC) and the European Court of Justice (ECJ) has provided the main jurisprudential nourishment for academic discussion on constitutional pluralism. The most recent set in this seemingly neverending game was played in 2014-16 in the Open Market Transactions (OMT) case. In the focus of the case lay the Open Market Transactions Programme, which the European Central Bank had announced in August 2012 to calm the sovereign debt market in Europe and put a stop to the debt crisis which had ravaged the eurozone ever since spring 2009. The programme was never put into action, but the mere announcement of the ECB's readiness to support fledgling euro-state finances through transactions in secondary bond markets contributed to pacifying the financial turmoil. The juridical issue, of course, did not concern the economic consequences, but the legal validity of the programme. Here both the German constitutional law, with the Court in Karlsruhe as its spokesman, and EU law, through the mouthpiece of the ECJ, claimed jurisdiction. What arose was a typical instance of jurisdictional contestations which in recent decades have been conceptualized as manifestations of legal or constitutional pluralism.

I shall use the OMT to highlight two alternative readings of legal and constitutional pluralism: conflictual and dialogical. The conflictual reading emphasizes that no higher principle or neutral arbiter exists to resolve a controversy between contending jurisdictions - in our case, German constitutional law and EU law. Legally speaking, a pluralist situation of contending claims of authority always entails the possibility of unresolved conflicts. In turn, without denying the existence or relevance of jurisdictional controversies, the dialogical reading cautions against overdramatizing them and draws attention to the potential of crossjurisdictional dialogue and cooperation; in brief, a peaceful solution to jurisdictional conflicts. Two main versions of the conflictual reading exist: Kelsenian and Koskenniemian. The Kelsenian one is premised on the assumption of independent and incompatible basic norms (Grundnorm) which the judicial representatives of diverse legal orders, such as EU law and Member State national law, are bound to obey. In turn, the Koskenniemian variant evokes judicial turf war, antagonistic strategic interests and institutional biases. These two approaches start from very different theoretical premises but they both lead to a solipsist conception of

1 The articles have been collected in Neil MacCormick, Questioning Sovereignty (Oxford University Press 1999). 
legal orders and systems; they epitomize what can be called radical pluralism. ${ }^{2}$ In this chapter, I will be particularly interested in the Kelsenian version of radical pluralism, which I will examine in the wider framework of legal perspectivism. Through a criticism of the Kelsenian position and giving its inherent perspectivism a culturalist twist, the potential for crossjurisdictional cooperation can be shown and a case made for a more dialogical reading - dialogical pluralism.

Let me, however, start with some conceptual clarifications.

\section{DIVERSITY AND PLURALISM}

What exactly do we mean by constitutional or legal pluralism? First, legal pluralism should be distinguished from what in Scandinavian debates has been called polycentricity of law. Polycentricity refers to important developments in the doctrine of legal sources, which determines who is allowed to participate in the continuous discourse specifying the contents of the legal order and what weight the respective contributions carry. Polycentricity connotes a multiplication of sources of law and reflects new participants' access to the discourse where the ever-changing substance of the legal order is determined. Moreover, the weight of individual contributions can no longer be defined in such an unequivocal and hierarchical manner as has been previously assumed in, for instance, Scandinavian doctrine; the formal authority of institutional statuses has been forced to give way to the substantive authority of well-argued interventions. ${ }^{3}$

Growing polycentricity shakes some of the premises of modern legal theory, and especially of the legal positivism of the Kelsenian or Hartian type, with its hierarchical view of law. It also questions the Continental European fiction of a unitary state will expressing itself in law and tends to turn the law's comprehensive consistence and coherence into a chimera. Still, the focus of polycentricity is on trends within a single legal order or system; it evokes a plurality of legal sources and not of legal orders or systems.

Secondly, a conceptual distinction should be made between legal diversity and legal pluralism. Pluralism is not identical to, but a special case of, diversity. Legal diversity refers to the mere coexistence of a plurality of legal orders or systems, without any implication of either harmonious or conflictual relations among them; indeed, 'legal diversity' can be used synonymously with 'legal plurality'. The black-box model which, according to William Twining, has underpinned much of modern legal theory, depicts legal diversity in terms of self-contained and self-sufficient normative and institutional boxes. This model is premised on the (co-)existence of territorially differentiated state legal orders, each claiming exclusive jurisdiction within their respective territorially defined social spaces, and international law, confined to regulating external relations

2 See my discussion of Kelsen and Koskenniemi in Kaarlo Tuori, European Constitutionalism (Cambridge University Press 2015) 79.

3 Henrik Zahle, 'The Polycentricity of the Law or the Importance of Legal Pluralism for Legal Dogmatics' in Hanne Petersen and Henrik Zahle (eds), Legal Polycentricity: Consequences of Pluralism in Law (Ashgate 1995) 185. 
among sovereign states. In internal legal relations, sovereign states are expected to treat each other according to the principle of exclusivity, that is, as black boxes. Furthermore, within their respective territorial confines, states raise the claim of, and mutually acknowledge, the universal scope of their exclusive legal sovereignty. ${ }^{4}$

The black-box model has clearly influenced the Kelsenian-Hartian way of conceiving of law. ${ }^{5}$ Yet, it is doubtful whether the black-box model has ever produced an accurate view of the global lawscape. The heyday of modern, sovereign nation states produced some corroboration for it, but even then the model's applicability was restricted to the law's surface level. When including the underlying legal-cultural levels in our examination, the illusion of nationally differentiated, mutually enclosed legal orders rapidly dissipates. Deficient as it is, the black-box model serves as an illustration of a particular but also influential understanding of legal diversity, that is, of plurality of law, which allows no room for pluralist constellations.

Legal diversity turns into legal pluralism when state law's exclusive jurisdiction is challenged; when the legal space of a state is transformed into a hybrid space where plural and overlapping claims of authority are raised. ${ }^{6}$ Legal pluralism is impossible to conceptualize within the black-box model. Legal pluralism comes in two guises: as pluralism of legal orders or pluralism of legal systems, or, in other words, normative or systemic pluralism. The distinction between the two variants is based on the distinction between two aspects of law. On the one hand, law is a symbolic-normative phenomenon, a legal order. On the other, it consists of specific social practices - legal practices - where the legal order is produced and reproduced. Legal practices take place in a particular institutional setting: lawmaking in parliament and government, adjudication in courts and legal scholarship at law faculties, to enumerate the primary practices of modern law. In my conceptual scheme, legal system covers both of the law's two dimensions: the legal order and institutionally framed legal practices. In Hartian terms, the existence of a distinct legal order presupposes distinct rules of recognition (a normative doctrine of legal sources), determining the criteria of membership in this order. ${ }^{7}$ For the existence of a distinct legal system, such a recognizable and definable legal order will not suffice. What is further required is institutional independence which facilitates the differentiation of legal practices as well, and first of all, the establishment of courtlike dispute-resolving or sanctioning bodies responsible for enforcement of the legal order. ${ }^{8}$

In a pluralism of legal orders (normative pluralism), more than one legal order claims authority in the same legal space, that is, the same geographically delineated social space as the setting for law. Such a situation challenges not only the hierarchical view of the Kelsenian-Hartian variant of legal positivism but also the exclusivity of

4 William Twining, Globalisation and Legal Theory (Northwestern University Press 2000).

5 It must, though, be emphasized that in his analysis of the relationships between national and international law, Kelsen was no hard-headed black-boxist, but pointed to both mutual dependence and potential substantive overlap.

6 Paul Schiff Berman, 'Global Legal Pluralism' (2007) 80 S Cal L Rev 1155.

7 Here I am addressing the legal order as it appears at its surface level. Below, I shall extend the concept of legal order to include even 'subsurface', legal-cultural levels.

8 I have developed a general view of law in my Critical Legal Positivism (Ashgate 2002) and Ratio and Voluntas (Ashgate 2011). 
state law. Yet, the challenge need not be fatal, and state law may still retain its dominance. This is the case when state law defines the conditions for the authority and applicability of nonstate law and when enforcement of the latter too falls to state courts..$^{9}$ In turn, pluralism of legal systems (systemic pluralism) contests the exclusivity of not only the state legal order, but of state legal institutions and practices as well. This occurs when nonstate law, claiming authority in the territory of a state, possesses its own courtlike, law-enforcing bodies. Evidently, this form of legal pluralism constitutes the gravest threat to the state-sovereigntist premises of the black-box model.

The concept of legal pluralism stems from legal anthropology. Yet, present legal pluralism is to a large extent a product of the fairly recent rise of transnational law. Transnational law, of which EU law is the most conspicuous example, has dealt the final deathblow to the black-box model. Transnational law is law beyond the dichotomy of national and international law; it cannot be compressed into the compartments of the black-box model. In the black-box model, legal systems and the reach of their respective claims of authority are differentiated along territorial criteria; within its territory, the claim to authority of the state legal system is universal and exclusive. It is universal in the sense of covering all substantive fields of law, and it is exclusive in the sense of not recognizing any rival legal authority. By contrast, transnational law follows not territorial but functional or substantive criteria of differentiation. Its claim to authority is not universal in its scope but always limited to specific substantive fields. This is true even of EU law, which, in spite of its ever more conspicuous expansionist tendencies, is bound by the principle of conferral, explicitly enshrined in Article 5(2) TEU. As a rule, transnational law's claim to authority is not exclusive, either. There are exceptions to this rule, though, as is proved by Treaty provisions on exclusive EU legislative competence (Articles 2(1) and 3 TFEU). Transnational law contests state law's claim to both exclusivity and universality. Clashes arising from contradictory principles of attribution of legal authority seem inescapable: transnational law's substantively limited claims of jurisdiction contradict state law's universal and exclusive claim. EU law has buttressed its claim of authority within its substantively limited field of jurisdiction with the principles of primacy and direct effect. Member State constitutional courts - or other courts of constitutional jurisdiction - as guardians of the autonomy of the national legal order have never accepted the principle of EU law's primacy without reservations. Reservations raised by national courts have created a minefield of potential conflicts. What we observe in the European legal space in the relationships between EU law and Member State law is not only normative but even systemic pluralism. The overlapping and potentially conflicting claims of jurisdiction are ultimately brought up by diverse institutions; that is, the ECJ and the respective national constitutional court (or other national court with constitutional jurisdiction).

By contrast, the constellation among Member State laws does not amount to normative or systemic pluralism but remains 'simple' diversity; as a rule, Member State law does not claim authority within the legal space of other Member States. The EU law principle of mutual recognition entails that national legal acts may have legal

9 See Ralf Michaels' discussion of the alternatives for state law to acknowledge the significance of non-state law. Ralf Michaels, 'The Re-State-Ment of Non-State Law: The State, Choice of Law, and the Challenge from Global Legal Pluralism' (2005) 51 Wayne L Rev 1209. 
effects in other Member States too, though, and application of this principle may attach a hint of pluralism to the horizontal relations among Member State legal systems. Member States may attach qualifications to recognizing legal acts of other Member States, analogous to those that condition their acceptance of the primacy of EU law. The scope of mutual recognition also covers fundamental rights-sensitive areas, such as criminal procedure (European Arrest Warrant) and asylum policy (Common European Asylum System). Hence, a Member State may attach conditions, drawn from fundamental rights order, to its EU law obligation to recognize another Member State's interpretation and application of, say, the right to fair trial or the principle of refoulement, even where this runs against its own. Yet, strictly speaking, here the pluralistic, potentially conflictual relationship prevails between EU law and the national law of the Member State under the obligation drawn from the principle of mutual recognition, and only indirectly between the two Member State legal systems.

The example of mutual recognition shows that even 'simple' legal diversity as such can become an issue for EU law. Indeed, overcoming problems which European legal diversity creates for the functioning of the internal market, and especially for free movement, is a major - if not the major - objective of European integration as legal integration. EU constitutional law avails itself of specific legislative instruments and doctrinal means to surmount these problems, such as directly effective Treaty provisions, directly applicable regulations and harmonizing directives, all of them backed up by EU law's primacy over conflicting national law. The principle of mutual recognition is the lightest weapon in this arsenal: it aims at the effects of diversity, not diversity itself.

\section{RADICAL AND DIALOGICAL PLURALISM IN ACTION}

Let us now return to the OMT case and the interventions where the GCC and the ECJ presented their jurisdictional claims. In July 2014 the German Constitutional Court held as admissible three applications which claimed that the OMT programme exceeded the ECB's Treaty-based mandate and that the ECB had acted ultra vires. ${ }^{10}$ The programme pursued, so the applicants argued, economic purposes external to the ECB's exclusive monetary policy focus and, furthermore, violated the explicit prohibition of central bank financing in Article 123 TFEU. The independence of the ECB constitutes an exception of the requirement of democratic legitimation and is only justifiable by the monetary policy focus pursuing a price-stability objective. Therefore, so the applicants' argument went, the OMT programme also contradicted Germany's inviolable constitutional identity, which includes the principle of democracy. Holding the applications admissible, the Court engaged in both ultra vires and identity review - two forms of constitutional review which, according to its previous caselaw, were available to it for assessing EU acts by national constitutional standards.

What further complicated the OMT case was that the German constitutional legislator has transformed central EU law parameters, which define the mandate and the institutional position of the ECB, into national constitutional standards. According

10 Beschluss vom 06. Juli 2010 - 2 BvR 2728/13. 
to Article 88 of the German Grundgesetz (GG), responsibilities and powers of the Federal Bank may, within the framework of the European Union, 'be transferred to the European Central Bank, which is independent and committed to the overriding goal of assuring price stability'. Thus, the independence of the ECB and its monetary policy mandate, specified through the overriding goal of price stability, are requirements of not only EU law but German national constitutional law, too. From the national constitutional perspective, this provides justification for the GCC's forays into overt and extensive interpretation of EU Treaty law - an exercise which Article 19(1) TEU reserves for the ECJ.

In its previous caselaw the German Constitutional Court had held that in ultra vires review of EU acts by EU institutions, the referring court must provide the ECJ with an opportunity to take a position on Treaty interpretation. As the Constitutional Court now dealt with the applications as the first instance, adherence to this procedural requirement, spelled out emphatically in Honeywell (2010) ${ }^{11}$ and justified with the principle of Europarechtsfreundlichkeit, led to the first ever request for a preliminary ruling from Luxembourg by the GCC in February 2014. In June 2015, the ECJ issued its ruling, in which it enumerated certain conditions under which the OMT programme fell under the ECB's monetary policy mandate. ${ }^{12}$ In June 2016, the German Constitutional Court gave its final ruling, in which it accepted that the ECJ's construction of the OMT programme was legally possible. It further stated that if the conditions specified by the ECJ were fulfilled, the OMT programme would not have to be considered ultra vires from the perspective of German constitutional law. ${ }^{13}$

In line with previous acts in the contestation between the ECJ and the GCC - such as the Solange saga, so important in the development of EU fundamental rights, ${ }^{14}$ or the Maastricht and Lisbon decisions by the GCC, in which the GCC reaffirmed its jurisdiction to review EU acts - the OMT case has engendered contradictory interpretations of the decisions and their more general implications for constitutional pluralism. Once again, a conflictual reading stresses that no overriding principle or neutral arbiter exists to resolve incongruences between assessments by constitutional actors of diverse legal systems both claiming jurisdiction in the same issue. And, once again, a dialogical reading discerns willingness to cooperate, as well as common cultural resources facilitating discourse over crossjurisdictional boundaries.

The OMT reference was the first ever request for a preliminary ruling by the GCC. This could already in itself be seen as a reconciliatory gesture, by which the German Court would have acknowledged the ECJ's mandate to 'ensure that in the interpretation and application of the Treaties the law is observed' (TEU 19(2)). By the same token, the GCC would have recognized that it stands under the duty which the Treaty on the Functioning of the European Union (TFEU) imposes on Member State courts of highest jurisdiction: namely, to request a preliminary ruling from the ECJ on the interpretation of the Treaties or the validity and interpretation of acts of the institutions, bodies, offices or agencies of the Union, where such a question is raised in a case

11 Beschluss vom 06. Juli 2010 - 2 BvR 2661/06.

12 C-62/14 - Gauweiler and Others.

13 Urteil vom 21. Juni 2016 - 2 BvR 2728/13.

14 See my succinct exposition in European Constitutionalism, supra fn 2, 90. 
pending before the court (TFEU 267(1)-(3)). However, these acknowledgements did not come without significant reservations, fuelling a conflictual reading of the pluralist situation.

In two important respects, the GCC's reference was exceptional and, at least for observers adopting an EU law perspective, probably even outright arrogant. In its reference, the German Court went to great lengths in explaining to the ECJ what the correct interpretation of the Treaty provisions pertaining to the mandate of the ECB would be. In so doing, the Court clearly exceeded the boundaries of what a reference by a national court is expected to do: namely, report on the facts and the relevant national law, explain how the outcome of the case is dependent on the interpretation of EU law and formulate the question to be posed to the ECJ. The GCC did not deny the jurisdiction of the ECJ, but it considered itself competent to instruct the latter Court as to how it should use its jurisdiction. The GCC also implied that it by no means deemed it irrelevant whether or not its instructions were followed. It clearly intimated that it would not consider itself bound by whatever interpretation the ECJ would embrace. It implied that it would consider the preliminary ruling of the ECJ as a stage in German ultra vires review, where it had the final say even over the significance of the ECJ ruling for German constitutional law. Already in Honeywell, the German Court had argued that German constitutional ultra vires review covered the rulings of the ECJ too; even these rulings could be ultra vires so that German state organs, including the Constitutional Court, would be not only entitled but even obliged to ignore them.

In its reference, the GCC restated the premises of its previous caselaw on national constitutional review of the acts of EU institutions. The Court reestablished its position that under the German constitution it possesses competence of both ultra vires and identity review. The constitutional basis for ultra vires review lies in Article 23(1) GG, which empowers the Federation, with the consent of the Bundesrat, to transfer sovereign powers to the EU by a law; here, according to the GCC, also lies the national constitutional basis for the principle of conferral. In turn, the constitutional anchorage of identity review is to be found, in addition to Article 23(1), in the 'eternity clause' (Ewigkeitsklausul) of Article 79(3) GG, which declares certain constitutional principles unamendable. These include federalism and human dignity, enshrined in Article $1 \mathrm{GG}$, as well as the foundational principles of a democratic Rechtsstaat, enshrined in Article 20 GG. The inviolability of these principles limits the constitutional mandate to transfer sovereign powers to the EU: such a transfer cannot be constructed to have implied breach of the unamendable principles, defining the inviolable constitutional identity. As the German Court summed up its caselaw, 'whether the principles which are declared inviolable by Art. $79 \mathrm{sec} .3 \mathrm{GG}$ are affected by an act of the European Union is subject to review by the Federal Constitutional Court via a review of identity' (para. 27).

The principle of Europarechtsfreundlichkeit requires in both ultra vires and identity review that the ECJ be granted, through the preliminary ruling procedure, an opportunity to assess the validity of and/or interpret the contested EU act. This requirement, reconfirmed in the reference, mellows the affirmation of national competence with a dialogical tone. So, at least on the face of it, does the characterization of the relationship between the GCC and the ECJ as 'cooperative'. However, a conflictual reading would see in the German Court's definition of the cooperative relationship a reassertion of the independence of national constitutional review of EU acts. In this 
relationship, 'it is for the Court of Justice to interpret the act'. In turn, the Constitutional Court takes the interpretation given in a preliminary ruling 'as a basis'. Yet, the Constitutional Court continues, in this cooperative relationship, 'it is for the Federal Constitutional Court to determine the inviolable core content of the constitutional identity, and to review whether the act (in the interpretation determined by the Court of Justice) interferes with this core' (para. 27).

All the main principles by which the German Court staked out its position on national constitutional review of EU acts have their counterparts in EU constitutional law. The principles of conferral, respect for national (constitutional) identity and sincere cooperation are principles of EU (constitutional) law, too. However, to defend its jurisdiction as the guardian of these principles, the German Court was careful to anchor them in the German constitution instead of EU constitutional law. Thus, the reference stresses that national constitutional identity review is different from the review under Article 4(2) TEU by the ECJ, 'based on a concept of national identity which does not correspond to the concept of constitutional identity within the meaning of Art. 79 sec. 3 GG' (para. 29). ${ }^{15}$ Not only are the identity concepts different but their respective legal weight varies too. According to the German Court, the ECJ has treated respect for national identity under Article 4(2) TEU as a legitimate interest, which may be balanced against other interests, while the constitutional identity within the meaning of Article 79(3) GG does not allow for any balancing.

As was to be expected, the assertive tone of the reference did not go unnoticed in Luxembourg. In the division of labour between the Advocate General and the Court, articulation of the reaction to the challenge from Karlsruhe fell to the former. In its ruling, the ECJ restricted itself to meeting the argument, put forth by the Italian government, that the request should not be examined because the referring court does not accept the binding and definitive interpretative value of the ECJ's answer. Rather bluntly, the Court stated that 'it must ... be borne in mind that it is settled case-law of the Court that a judgment in which the latter gives a preliminary ruling is binding on the national court, as regards the interpretation or the validity of the acts of the EU institutions in question, for the purposes of the decision to be given in the main proceedings' (para. 16).

By contrast, in his Opinion, ${ }^{16}$ AG Cruz Villalón dwells long on the 'functional' difficulty arising from the reference's insertion of the preliminary ruling procedure in the national constitutional review, where the ultimate jurisdiction, even with regard to the validity and interpretation of the EU act, lies with the national constitutional court. He also points to the German Court's emphasis on the differences in the criteria of ultra vires and identity review employed by the ECJ and the GCC, which implies the possibility of the two courts arriving at different conclusions. Furthermore, the Advocate General evokes the exceptionality of the premise of the reference: namely, the finding that an EU body or authority has seriously breached the limits of the

15 According to Art. 4(2) TEU, 'the Union shall respect the equality of Member States before the Treaties as well as their national identities, inherent in their fundamental structures, political and constitutional, inclusive of regional and local self-government'.

16 Opinion of Advocate General Cruz Villalón delivered on 14 January 2015, C-62/14 Gauweiler and Others. 
competences derived from the Treaties. In effect, the German Court asks whether the ECJ - from its EU law perspective, we might add - agrees with the preliminary findings, arrived at from the perspective of the national constitutional law. In addition, the German Court appears to reserve for itself the right to assess the significance of the ECJ's divergent conclusion for the national constitutional review. Yet, as AG Cruz Villalón argues,

the preliminary ruling procedure was, in fact, never conceived of as a mere 'opportunity' for the Court of Justice to 'concur' with the national court, either on a finding of ultra vires or on something else, with the possible consequence that any 'failure to concur' on the part of the Court of Justice could render its answer nugatory.

He also points out that 'in such circumstances, a request to the Court of Justice to give a preliminary ruling could even end by having the undesirable effect of embroiling the Court in the chain of events ultimately leading to the breakdown in the "constitutional compact" underlying European integration' (para. 52).

At this point, AG Cruz Villalón's argument seems to be heading towards an open conflict with the German Court, that is, towards concluding that what the German court has submitted to the ECJ is not actually a reference within the meaning of Article 267 TFEU. However, by a somewhat surprising and not wholly convincing argumentative volte-face, he manages to avoid such a conclusion, which also could be fatal to the 'constitutional compact underlying European integration'. Despite the German Court's insistence on the different yardsticks used in national and EU review, the Advocate General assumes the criteria for ultra vires to be by and large the same. In both EU and national review, the assessment of the validity of the OMT programme largely depends on the interpretation of the ECB's mandate, and here the crucial concept in both Article 127(1) TFEU and Article 88(1) GG is 'price stability'. This still leaves open the criteria of identity review, which, according to the reference, was also involved in the OMT case. Here the Advocate General takes notice of the GGC's emphasis on the cooperative relationship between the two courts, which, however - as he also notes - is modified by the insistence that it is for the German Court to 'determine the inviolable core of constitutional identity and to review whether the measure (as interpreted by the Court of Justice) encroaches on that core' (para. 56).

AG Cruz Villalón makes two general observations of identity review. First, he argues that maintaining the EU in its present shape would become all but impossible if it were subject to reservations of each Member State in terms of a constitutional identity defined by the state concerned and conceptually different from the national identity within the meaning of Article 4(2) TEU (para. 59). Yet, secondly, even in identity review the Advocate General finds a counterweight which works against the diversification of nationally independent criteria. He evokes the notion of a common constitutional culture which, according to him, forms part of the common identity of the Union. He points to the fact that 'the Court of Justice has long worked with the category of "constitutional traditions common" to the Member States when seeking guidelines on which to construct the system of values on which the Union is based', giving 'preference to those constitutional traditions when establishing a particular culture of rights'. Thus, 'the Union has thus acquired the character, not just of a community governed by the rule of law, but also of a "community imbued with a 
constitutional culture"'. This observation is backed up with a reference to an article by Andreas Vosskühle, the current president of the GCC. From the formation of a common constitutional culture, defining for its part the common identity of the Union, AG Cruz Villalón concludes that 'the constitutional identity of each Member State, which of course is specific to the extent necessary, cannot be regarded, to state matters cautiously, as light years away from that common constitutional culture'. On the contrary, it is to be expected is that 'a clearly understood, open, attitude to EU law should in the medium and long term give rise, as a principle, to basic convergence between the constitutional identity of the Union and that of each of the Member States' (para. 61).

In sum, on AG Cruz Villalón's account, in both ultra vires and identity review at least a partial convergence of criteria appears to be plausible, which facilitates a dialogical relationship between the national and the transnational courts. This still leaves open the question whether the 'functional difficulty', that is, the risk of transnational EU review being 'manipulated' for the purposes of national constitutional review, can be overcome. AG Cruz Villalón finds this to be the case, albeit for reasons which do not sound entirely convincing in the whole of his argument. Now his lifebuoy consists of the principle of cooperation, enshrined in Article 4(3) TEU and invoked also by the German Court (although anchored in its own caselaw, instead of the Treaty provision). The Advocate General stresses that the principle is binding on both courts involved in the proceedings. On the part of the ECJ, the principle 'requires a particular effort ... to provide an answer on the substance to the questions referred', notwithstanding the 'functional difficulty' (para. 66). AG Cruz Villalón also states quite clearly what he expects from respect for the principle of sincere cooperation on the side of the German Court. He expresses the hope 'that, in the end, any subsequent review on the basis of the constitutional criteria would not, in the circumstances of the case, reach conclusions that were in open contradiction with the answer given by the Court of Justice' (para. 63). When applying, for its part, the principle of sincere cooperation, the ECJ 'would in fact trust the national court - once it has considered the answer provided by the Court of Justice to the question raised and without prejudice to the exercise of its own duties - to accept that answer as decisive in the proceedings before it' (para. 67).

In its final OMT judgment, the German Constitutional Court once more reconfirmed its position on the limits on EU law's primacy and its jurisdiction in both ultra vires and identity review. Defiantly enough, the GCC considers it appropriate to reaffirm its alleged jurisdiction to subject even the ECJ's rulings to an ultra vires review; according to the Court's argument, even the ECJ exercises a competence transferred by the Member States - for Germany's part, in accordance with Article 23(1) GG - and even the ECJ is subject to the principle of conferral, derived from not only EU Treaty law but also national constitutional law. Yet, the German Court concedes to the ECJ the benefit of the doubt. A finding in a national constitutional review requires that the transferred competence be manifestly exceeded. The German Court generously allows its Luxembourg interlocutors 'a right to tolerance of error', which, however, 'reaches its limit ... when an interpretation of the Treaties is manifestly utterly incomprehensible and thus objectively arbitrary' (para. 149). If the ECJ were to cross that line, its actions would no longer be covered by Article 19(1) TEU and it would, for the 
purposes of German constitutional review, act ultra vires. ${ }^{17}$ This is the German Court's reply to the ECJ's unconditional reminder of the binding nature of preliminary rulings: the GCC claims jurisdiction to deviate from preliminary rulings because of not only the different standards applied in EU and national review, but also the subjection of these rulings too to constitutional ultra vires review under national standards. What on its face appears a concession includes another reassertion of the ultimate jurisdiction over the significance of ECJ rulings' national identity and ultra vires review: 'as long as the Court of Justice applies recognised methodological principles and does not act in a way that is objectively arbitrary, the Federal Constitutional Court must respect judicial development of the law by the Court of Justice even when the Court of Justice adopts a view against which weighty arguments could be made' (para. 161). It remains the GCC that will assess whether the ECJ applies 'recognised methodological principles' and 'does not act in a way that is objectively arbitrary'.

In essence, that is exactly what the GCC does in its final OMT judgment. The German Court subjects the preliminary ruling to quite severe substantive criticism, ${ }^{18}$ but arrives at the conclusion that 'the Court of Justice's finding that the policy decision on the OMT programme is within the bounds of the respective competences and does not violate the prohibition of monetary financing ... still remains within the mandate of the Court of Justice in accordance with Art. $19 \mathrm{sec} .1$ sentence 2 TEU'. In this way, both parties to the 'cooperative relationship', both paying lip service to the national and transnational principles of sincere cooperation, avoided bringing the conflict to a head - without, however, relinquishing their claims to ultimate jurisdiction in ultra vires and constitutional review. The German Constitutional Court based its autonomous jurisdiction, unrestricted by the EU law competence of the ECJ, on the national constitution: in ultra vires review on the principle of conferral drawn from Article 23(1) GG, allowing for transfer of sovereign power by law to the EU; and in identity review on the inviolability of constitutional identity, as defined through the constitutional principles defined unamendable by Article 79(3) GG. In turn, the ECJ backed up its Kompetenz-Kompetenz, as well as the binding and final nature of its findings on interpretation and validity of EU law, through Article 19 TEU and Article 267 TFEU; that is, the 'constitutional charter of the EU'.

As neither of the two courts was willing to compromise over the fundamental issue of ultimate jurisdiction, an open and legally unresolvable conflict remained a possibility until the very last act of the judicial drama: the final judgment of the German Court. When also taking into account the general tone of both the German reference and the final judgment, which must have sounded provocative to Luxembourg's ears, a

17 The German Court also argues that the ECJ is bound by traditional European methods of interpretation and common general legal principles: 'The mandate of Art. 19 sec. 1 sentence 2 TEU does not allow manifestly ignoring the traditional European methods of interpretation or, more broadly, the general legal principles that are common to the legal systems of the Member States' (para 160).

18 Thus, the Court claims that ' $(\mathrm{t})$ he manner in which the law was interpreted and applied in the Judgment of 16 June 2015 meets with serious objections on the part of the Senate in respect of the establishment of the facts of the case ... the principle of conferral ... and the judicial review of acts of the European Central Bank that relate to the definition of its mandate' (para. 181). 
conflictual reading of the most recent chapter in the (hi)story of European constitutional pluralism seems more than justified. Still, the judicial interventions included not only reciprocal assertions of overlapping and - in case of irresolvable substantive disagreements - incompatible jurisdictions, but also assurances of readiness for sincere cooperation and respect for viewpoints embraced by the interlocutor, as well as references to normative and methodological common ground, which was expected to facilitate compatible substantive outcomes. Indeed, in the end, an overt judicial clash was avoided. Consequently, a dialogical reading of the interventions is plausible too. Alternative interpretations are available, as they are of earlier chapters in the (hi)story of European constitutional pluralism; say, the Solange saga, so central for the emergence of the fundamental rights dimension of EU (EC) law. The case is susceptible to a pronouncedly conflictual account, where the emphasis lies on successive efforts to enhance the jurisdictional authority of the respective courts, the GCC and the ECJ. But the judicial speech acts give support to a dialogical version as well: a version recounting a cooperative search for comprehensive fundamental rights protection in European legal and constitutional space.

\section{THE POSSIBILITY OF LEGAL CULTURAL INTERLEGALITY}

Hans Kelsen has been an important source of inspiration for debates on legal and constitutional pluralism. Neil MacCormick, the main instigator of these debates, was no orthodox Kelsenian; indeed, he was a student of H. L. A. Hart and developed his own version of institutional legal theory. However, he exposed the dilemma of European constitutional pluralism, especially such as it is condensed in conflicting claims of Kompetenz-Kompetenz, in consciously Kelsenian terms. The Kelsenian account of legal and constitutional pluralism ultimately fails. But, as I will try to show, even in its failure this account can still be instructive. It points to two fundamental issues of pluralism: it connects pluralism to perspectivism and it can be used to demonstrate the fruitfulness of a legal-cultural approach.

Perspectivism is an inherent feature of all law. Legal actors always approach the law from a particular perspective, which inevitably affects what they identify as law and how they interpret and apply it. Law exists only as identified and interpreted by situated legal actors; that is, legal actors embedded in a particular social and cultural context. How legal perspectivism is conceived of depends on how the situatedness of legal actors is defined. Kelsen's pure theory of law is an attempt to reconstruct law's internal point of view. Kelsen conceives of the legal order as a hierarchically organized whole, where lower-order norms derive their validity from higher ones: bylaws from laws, laws from the constitution and the (historically first) constitution from a hypothetical, presupposed basic norm (Grundnorm). Multiple interpretations of the nature of the Grundnorm exist; indeed, Kelsen's own accounts of its role vary as well. But a Kantian transcendental aspect, at least, is crucial to understanding the function of the Grundnorm in the pure theory of law. For Kelsen, the tacit assumption of a Grundnorm is a necessary precondition for all legal cognition and all judgments of legal validity. On Kelsen's view, the inevitability of legal perspectivism of law results from the inevitability of adhering to the Grundnorm of a particular legal order. Consequently, it is the 
Grundnorm which defines the situatedness of a legal actor. Kelsen's is a variant of exclusive perspectivism: no connections can bridge the gulf separating legal orders, each supported by their particular Grundnorm.

In some passages, Kelsen seems to contend that normative perspectivism (of which legal perspectivism is a subspecies) is a matter of personal choice. As I want to claim, such passages have led some commentators, such as Joseph Raz, astray in their discussion of Kelsen's views. In his comments in his essay Kelsen's Theory of the Basic Norm, ${ }^{19}$ Raz has distinguished between two alternative accounts of legal normativity: justified and social. Those embracing the former require of legal normativity that it be justified, either by objective and universally valid reasons, or through personal commitment or intuitive perception of the binding character of the norms. Those espousing the social nature of legal normativity treat legal norms as social norms which are socially upheld as binding standards of behaviour; law is alleged to be normative because of certain social facts, not because it is just.

Raz contends that Kelsen considered that legal normativity justified normativity, and as the reason for legal normativity is the basic norm, the basic norm must be understood to be a justified norm. As Kelsen was a moral relativist, the basic norm cannot be just in any absolute or objective sense, but only for subjective reasons. Here Raz invokes passages in which Kelsen characterizes adoption of the basic norm as a choice, which, say, an anarchist or a communist may refuse. Raz concludes that Kelsen 'claims that the basic norm is presupposed, i.e., accepted, and the law is regarded as normative only by people who consider it to be just'. ${ }^{20}$ But Kelsen makes no such claim, nor does the non-necessity of presupposing the basic norm imply such a claim. According to Kelsen, the basic norm is presupposed by 'those who interpret the coercive order as an objectively valid normative order', but 'the system of norms that we call 'legal order' is a possible but not a necessary scheme of interpretation'. ${ }^{21}$ To adopt the legal order as a scheme of interpretation is not a moral but a cognitive choice, and the basic norm is not a moral but an epistemological presupposition. ${ }^{22}$

Raz's interpretation collapses Kelsen's strict separation of law and morals at the very heart of the pure theory of law. Raz treats social and justified normativity as the only available alternatives for understanding legal normativity and defines the latter in moral terms, as related to justice. Yet, Kelsen's constitutive separations of Ought from Is and

19 Joseph Raz, The Authority of Law (Clarendon Press 1979) 122.

$20 \quad$ Ibid. 137.

21 Hans Kelsen, What Is Justice (University of California Press 1957; Lawbook Exchange edn 2013) 226.

22 In a footnote in the second edition of Pure Theory of Law, Kelsen tries to dissipate misunderstandings created by his earlier writings and to state as explicitly as possible that an individual's adoption of the basic norm does not imply any moral commitment or acceptance of the legal order: '[T]he doctrine of the basic norm is not a doctrine of recognition as is sometimes erroneously understood. According to the doctrine of recognition positive law is valid only if it is recognized by the individuals subject to it, which means: if these individuals agree that one ought to behave according to the norms of the positive law. This recognition, it is said, actually takes place, and if this cannot be proved, it is assumed, fictitiously, as a tacit recognition.' Hans Kelsen, Pure Theory of Law, second edn (University of California Press 1967; Lawbook Exchange edn 2009) 218 fn 83. 
legal Ought from moral Ought led him to reject both of these alternatives and opt for 'pure' or formal legal normativity beyond and independent from not only social facts but also (objective and subjective) moral norms. For Kelsen, legal normativity is distinct from both social facts and morals, and this makes the basic norm a necessary presupposition for not only legal cognition, but legal normativity in general. Yet, as I have already intimated, Kelsen ultimately fails. He cannot explain how a Kantian epistemological presupposition - the basic norm as hypothetical, transcendental norm can have such momentous consequences as the establishment of legal normativity.

Raz also misunderstands and overemphasizes the role of individual choice in Kelsen's conception of perspectivism. It is true that by invoking the personae of an anarchist and a communist, Kelsen wants to show that individuals may reject the basic norm and the legal order as a cognitive framework. However, this is not the only, and not even the most important, perspectivist point which Kelsen makes. The communist and the anarchist to which Kelsen alludes stand outside the law - the law now understood in an un-Kelsenian sense as consisting of specialized legal practices. Kelsen never argues that individual judges, legislators or legal scholars - that is, legal actors in a narrow sense of the term - would have a similar choice. Kelsen does argue that 'even an anarchist, if he were a professor of law, could describe positive law as a system of valid norms without having to approve of this law'. ${ }^{23}$ But what is important to add, although Kelsen leaves it unsaid, is that then even the anarchist law professor would have to presuppose the basic norm. And this he can also do, because, due to the purely epistemological nature of the basic norm, this presupposition does not, in Kelsen's view, imply any moral or political commitment to a particular legal order or law in general. The basic norm is presupposed by everybody engaged in legal cognition and treating the legal order as consisting of objectively valid norms. ${ }^{24}$ This certainly includes legal scholars - even anarchist or communist ones (if they have ever managed to get an appointment) - but it also includes legal actors in other legal practices, such as legislators, law drafters and judges. For Kelsen, both law creation and law application consist essentially of acts of will, but they both include a cognitive phase in which legal actors inevitably adopt the epistemological presupposition of the basic norm. Presupposing the basic norm and employing the objectively valid legal order as a frame of interpretation is a possibility but not a necessity for those standing outside specialized legal practices. By contrast, legal actors engaged in these practices - such as legislators, judges and scholars - cannot decline this presupposition. ${ }^{25}$

Raz's account of Kelsenian perspectivism must be complemented in yet another respect. One can use normative orders as a frame of interpretation, but, in Kelsen's

23 Ibid. 218 fn 82.

24 In another footnote in the second edition of Pure Theory of Law, Kelsen responds to the question of who presupposes the basic norm. The answer, in terms of the pure theory, is as follows: 'The basic norm is presupposed by whoever interprets the subjective meaning of the constitution-creating act, and of the acts created according to the constitution, as the objective meaning of these acts, that is as objectively valid norm.' And Kelsen adds that 'this interpretation is a cognitive function, not a function of the will': ibid. $204 \mathrm{fn} 72$.

25 In his discussion of the uncommitted or professional acceptance of the basic norm by legal science, Raz comes closer to Kelsen's epistemological. Unfortunately, space does not allow me to comment on this discussion. See The Authority of Law, supra fn 19, 140. 
contention, only one at a time. A spatiotemporal event can be interpreted in the light of both legal and moral norms but 'no one can serve two masters': 'no viewpoint exists from which both morals and law may simultaneously be regarded as valid normative orders' ${ }^{26}$ Kelsen also pointed to a possible substantive overlap between international and national law. Although international law mainly focused on interstate relations, no a priori limits to the reach of international law existed; this is an important qualification of Kelsen's adherence to the black-box model. Here too, one must choose the master one serves, and here too, the choice can be predetermined by the institutional position one holds in a legal system. Kelsen did not live to see the rise of transnational law, the main development in the background of the present discussion on legal and constitutional pluralism. Yet there exists no reason to doubt that Kelsen would have agreed with his followers on the radical pluralist position ensuing from the exclusive perspectivism imposed by diverse basic norms, such as those crowning transnational EU legal order and national Member State legal orders.

Kelsen helps to understand the connection between legal pluralism and perspectivism, as well as the importance of legal actors' preconceptions, that is, their Vorverständnis, for explaining the ubiquity of perspectivism in law. I would propose approaching legal Vorverständnis in terms of legal culture: legal Vorverständnis receives its contents from the legal-cultural layers which underpin the surface level of explicit legal speech acts, such as statutes, regulations and court decisions, and which also form an integral part of the legal order. The professional legal culture of professional legal actors includes normative elements, such as legal principles; conceptual elements, such as legal concepts; and methodological elements, such as a doctrine of legal sources, interpretative standards and patterns of legal argumentation. Against the backdrop of such a comprehensive understanding of legal culture, Kelsen's reconstruction of legal actors' Vorverständnis remains truncated.

Kelsen conceives of the subsurface, cultural elements of law merely in terms of its conceptual structure and a hierarchical doctrine of legal sources, culminating in the quasi-transcendental Grundnorm. Kelsen is right in stressing that a doctrine of legal sources which helps to identify valid legal norms is an essential part of this Vorverständnis, as is the law's basic conceptual structure, which he also attempted to pin down. But through his leap into the transcendental, Kelsen ahistoricizes historically highly variable cultural phenomena. As the debate on the increasing polycentricity of law, for instance, has shown, the doctrine of legal sources is not necessarily hierarchically structured, as Kelsen claims, nor does legal-cultural evidence support a thesis of the law's immutable conceptual skeleton. Perhaps even more serious is Kelsen's silence on the normative elements - legal principles - in legal culture and legal actors' Vorverständnis. The hypothetical and presupposed Grundnorm is supposed to ground in a rather mystical way, we can add - the positivity of the constitution (and through it the rest of the legal order), while the posited constitution regulates the manner in which other, lower-order legal norms are posited. Outside this basic function, the substantive contents of the constitution are purely contingent and at the discretion of the constitutional legislator. The same goes for the rest of legal order, the lower-ranking

26 Pure Theory of Law, supra fn 22, 329. 
legal norms: at all its alleged hierarchical steps, the contents of the legal order are up for grabs.

Still, I would rely on Kelsen, not only in connecting pluralism to perspectivism and explaining perspectivism through legal Vorverständnis, but also in stressing the role of a referential legal order. Kelsen provides support for the thesis that the normative claims of legal speech acts are always made with reference to a specific legal order. This is the backdrop to the perspectivism which Kelsenians have emphasized in the debate on European constitutional pluralism: for them, the multiplicity of alternative referential legal orders inevitably entails a multiplicity of views on the validity basis of European law. But what does it actually mean to adopt a particular legal order as one's normative framework and point of reference? For Kelsenians, this amounts to adherence to the Grundnorm of the legal order at issue, and this adherence accounts for the different views that the ECJ and national constitutional courts hold of the ultimate validity criteria of EU law, that is, the terms in which these courts pose the Kompetenz-Kompetenz issue. They have no choice but are bound to take the perspective of the legal order under which it has been set up and whose realization they are expected to guarantee. Indeed, the assumption of another Grundnorm would amount to a judicial revolution.

However, legal actors' dependence on a referential legal order should be understood in broader terms than merely the application of surface-level normative material or the doctrine of legal sources identifying and determining the legal validity of that material. We should also be aware of the general role which the legal culture informing the legal Vorverständnis of legal actors plays in legal practices; that is, the functioning of legal concepts, principles and theories as a filter through which surface-level legal material is cognized and interpreted. Rejecting the Kelsenian reading of legal perspectivism does not imply denying that national courts are still in an important way bound to their national legal order. Judges in national courts have received their legal education in national universities and have accumulated their professional experience in the national judiciary; consequently, their legal preunderstanding is permeated by the national legal culture. Hence, we are entitled to assume, for instance, that judges in national courts approach and interpret EU law through their national legal culture: through the legal concepts, principles and theories inherent in that culture. And, if we regard legal culture as an integral part of the legal order - as I think we should - we can speak not only of diverse perspectives on European law but also of diverse European laws, cast in different legal-cultural moulds. Arguably, EU law has also been able to develop its particular legal culture, consisting of specific EU law legal principles, concepts and methodologies, and, arguably, this is the legal culture which informs the Vorverständnis of the judges, Advocates General and legal staff of the ECJ; EU civil servants drafting and in some important fields - such as competition law - even implementing EU legislation; and the transnational community of EU law scholars. In addition to the 28 nationally divergent EU laws we also have the EU law of EU law; this is the EU law applied by the ECJ.

Above, I have maintained that a major - if not the major - objective of European legal integration is to overcome the problems produced by the diversity of national legal orders. The means that EU law offers for meeting this issue are tailored to deal with surface-level diversity. This goes for directly effective EU rules, harmonization 
through directives and the principles of primacy and mutual recognition. These means miss the legal-cultural diversity which operates through the Vorverständnis of legal actors. Member State courts function as bodies of both national and Union legal systems. It is realistic to assume that judges are not able to 'switch off' the deeply ingrained national legal culture when applying (surface-level) European law. Does this entail such a diversity of EU laws which jeopardizes the legal uniformity required by European integration? Through my theorizing, have I not produced another variant of exclusive perspectivism and radical pluralism, rooted in legal actors' largely unconscious Vorverständnis, which receives its contents from the cultural layers of law? Have I not replaced the Grundnorm of the Kelsenians and the antagonistic strategic interests of the Koskenniemians with legal-cultural idiosyncrasies guiding the interpretation and application of law?

The legal-cultural reading of pluralism and perspectivism possesses the potential to offer the solution to the problem of diversity it exposes. Radical pluralists shut off legal orders and systems in the solipsism of the particular perspectives imposed on them by their Grundnorms or by legal actors' strategic interests. The radicals are not able to account for phenomena of interlegality or the aspect of uniformity which balances the perspectivist diversity of EU law(s). A cultural view of legal perspectivism can overcome these shortcomings. Differences in legal or constitutional culture do not negate the possibility of a common core in nationally differentiated traditions; a common legal and constitutional deep culture. Legal cultures of different legal orders may share a common deep culture, which accounts for the possibility of legal-cultural interlegality. The transnational roots of Western national legal cultures are easy to demonstrate. Continental private law culture owes its emergence to the reception of Roman law, to which English common law has not been immune, either. In constitutional law, fundamental ideas of modern constitutionalism were launched in the early modern age by enlightenment thinkers and the spokesmen and constitution drafters of, especially, the French and American revolutions. During subsequent centuries, ideas with universalist pretensions received different interpretations and specifications in individual nation states, due to their particular historical trajectories and ethicopolitical self-definitions.

Despite European legal-cultural diversity, EU law is still by and large interpreted and applied in approximately the same way in the Member States. We may have 28 diverse EU laws, impregnated by diverse national legal cultures, complemented by the EU law. However, the diverse EU laws are sufficiently similar to make European integration possible. The necessary uniformity is guaranteed by European legal deep culture, which nationally differentiated legal concepts, principles and methodologies manifest and specify. It bridges legal diversity and facilitates ongoing crossborder dialogue, which is such an essential feature of European interlegality.

Interestingly, I seem to have arrived at conclusions analogical to the premises of the consensual and dialogical tone which AG Cruz Villalón used in his Opinion in the OMT case, alongside paragraphs more self-assertive and defensive of the ECJ's jurisdiction. Recall his emphasis on the similarities between the standards of EU and German national ultra vires and identity review, as well as his point concerning a common constitutional culture which gives rise 'to basic convergence between the constitutional identity of the Union and that of each of the Member States'. And even 
the German Constitutional Court, although perhaps more prone to stress the divergences rather than commonalities of national and EU constitutional principles, invokes a joint legal-cultural heritage, presumably shared by the ECJ: 'recognised methodological principles', 'traditional European methods of interpretation' and 'the general legal principles that are common to the legal systems of the Member States'. In sum, judicial sabre rattling is muted on both sides, in more conciliatory paragraphs, by references to legal-cultural interlegality. 